\title{
Overt Subjects in Raising and Control Complements and the Null Subject Parameter
}

Pilar P. Barbosa

Universidade do Minho/CEHUM

1. Introduction. Szabolsci (2009) discusses evidence that there are languages where control and raising infinitival complements have overt subjects. Her descriptive generalization is the following:

(1) The overt subjects of control complements can only be pronouns. The overt subjects of raising complements can be pronouns or lexical DPs.

The following data from European Portuguese (EP) show that this language complies with (1) (similar facts obtain in Italian, Spanish and Romanian as reported in Szabolsci (2009)). The examples in (2) contain a control verb. (2a) has the reading indicated in the gloss, with the DP in bold interpreted as the subject of the embedded clause; (2b) cannot be so interpreted:

(2) a. Decidiu ir ele ao mercado.

decided to-go he to-the market

' $\mathrm{He}_{\mathrm{i}}$ decided for it to be the case that he ${ }_{\mathrm{i}}$ goes to the market

b. Decidiu ir o João ao mercado.

decided to-go the John to-the market

*' $\mathrm{He}_{\mathrm{i}}$ decided for it to be the case that João $\mathrm{O}_{\mathrm{i}}$ goes to the market'

The contrast between the two examples can be explained under the assumption that the DPs in bold are in a low position, inside the embedded infinitival clause, in a VSO configuration. ( $3 \mathrm{~b})$ is ruled out as a Condition $\mathrm{C}$ violation:

(3)a. pro $_{i}$ decidiu [ ir $\mathbf{e l e}_{\mathbf{i}}$ ao mercado]

b. ${ }^{*}$ pro $_{i}$ decidiu [ ir o João ao mercado]

It is worth pointing out that these facts are not related to restructuring given that decidir 'decide' is not a restructuring verb. Likewise, it is not possible to relate these facts to lack of a CP projection (cf. Alexiadou et al. 2008)) given that these controlled pronominals can occur in infinitival complements introduced by an overt complementizer (cf. Torrego (1996) for Spanish and Belletti (2005) for Italian).

(4) Não sabemos [se assinar nós a carta ou não].

not know.1stP1 if to-sign we the letter or not

'We don't know whether the letter should be signed by us or not.'

When the matrix verb is a raising verb, however, the DP in bold may have embedded scope regardless of whether it is a pronoun or a lexical DP.

(5) Acabou por [ir ele / o João ao mercado].

ended up by to go he / the João to-the market

'It ended up being the case that he/João went to the market'

Thus, raising complements differ from control complements in that they do not require the subject in the embedded clause to be a pronoun or an anaphoric expression.

The facts just presented are particularly interesting in light of the current debate between Agree-based vs. movement theories of Obligatory Control (OC). Under the view of OC as raising (Hornstein 1999), one might be tempted to account for the facts just discussed in terms of backward control or backward raising (Polinsky and Potsdam (2002), whereby the subject of the infinitival clause is the Spell-out of the copy of the raised subject. However, the contrast between raising and control complements regarding non-pronominal subjects is not easily explained under this approach. Above, we attributed this asymmetry to a Condition $\mathrm{C}$ effect, but this account is lost under a backward control analysis, which would predict raising and control infinitives to behave alike with respect to the choice of the phonological shape of the pronounced copy.

2. Multiple subjects and emphatic pronouns. One other fact pointed out by Szabolsci 
(2009) as well as Belletti (2005) is that these control and raising complements may take multiple subjects.

(6) a. O João decidiu resolver ele o problema.

the J. decided to-solve he the problem

'John hated it that he was the one to solve the problem'

b. O João acabou por resolver ele o problema.

the J. ended up to-solve he the problem

'John ended up solving the problem himself.'

These examples are strongly reminiscent of the constructions with "emphatic pronouns" discussed in Burzio (1986) among others. In all of the languages under discussion, a pronoun may co-occur with an explicit pre-verbal subject in a simple sentence. The pre-verbal subject may be a full DP or even a pronoun:

(6) a. A Teresa / ela escreveu ela o poema (ninguém a ajudou).

the Teresa she wrote she the poem noone her helped

'Teresa wrote the poem by herself (noone helped her)'

In view of these examples, one might think that the pronouns in the embedded clauses in (6) are not genuine subjects, but rather some kind of anaphoric adjuncts. However, Barbosa (1995, 2009) and Cardinaletti (1999) have argued that emphatic pronouns are post-verbal subjects and that the DP that appears in front of the clause in (6) is Left Dislocated. In fact, emphatic pronouns cannot co-occur with a non-referential quantified phrase (similar facts obtain in Italian (cf. Belletti 2005)):

(7) *Nenhuma criança escreveu ela o poema.

no child wrote she the poem

Incompatibility with a non-referential quantified phrase is a standard test for Dislocation. Thus, we conclude that emphatic pronoun constructions are left dislocation (LD) constructions. We follow the line of approach that assumes that post-verbal subjects in the Romance NSLs are sitting in their base position inside the VP (Ordónez (1998), Zubizarreta (1998), Costa (1998), and Cardinaletti (1998)). Since the verb raises out of VP in Romance, the in situ subject surfaces to the right of $\mathrm{V}$ :

(8) $\left[\mathrm{TP}\right.$ escreveu $\left[\mathrm{vP}\right.$ ela $\mathrm{i}_{\mathrm{i}}$ escreveu o poema $\left.]\right]$

In addition, we adopt the "classic" analysis of LD that takes LDed topics to be basegenerated in the periphery of the clausal projection that is predicated of it (cf. Raposo 1994).

(9) [A Teresa $a_{\mathrm{i}} / \mathrm{ela}_{\mathrm{i}}$ ] [TP escreveu [vP ela $\mathrm{T}_{\mathrm{i}}$ escreveu o poema]]

Evidence that the control and raising complements with multiple subjects should be analysed along the same lines comes from the following contrast in the distribution of nonreferential QPs in raising vs. control complements. Unlike referring DPs (cf. (10a)), nonreferential QPs may not occur in a "multiple" subject construction with a raising verb (cf. $(10 b))$ :

(10)a. O hóspede acabou por fazer ele o pequeno-almoço.

the guest ended up to-do he the breakfast

'The guest ended up cooking breakfast himself.'

b. * Nenhum hóspede acabou por fazer ele o pequeno-almoço.

no guest ended up to-do he the breakfast

'No guest ended up cooking breakfast himself'

In (10a) the DP is a base-generated topic doubled by the pronoun which is the in situ subject of the infinitival clause. This configuration is not available in (10b) given that the non-referring expression nenhum hóspede 'no guest' cannot be a base-generated topic: it can only be merged as subject of the embedded clause and then raised to the matrix. Thus, there is no position for the subject pronoun to be merged in the embedded clause.

Now, control complements can take multiple subjects with a non-referential QP:

(11)Estou certa de que nenhum hóspede optará por fazer ele 
I-Am certain of that no guest will-choose to-make he

o pequeno almoço todos os dias.

the breakfast every the days

'I am certain that no guest will choose to prepare his breakfast himself every day'

The contrast between (10b) and (11) can be easily explained under the aasumption that the QP nenhum hóspede is merged as an argument of the matrix control verb. In this case, the pronoun is the subject of the infinitival clause and interpreted as a bound variable:

(12)[ [nenhum hóspede $]_{i}$ optará [ [nenhum hóspede $]_{i}$ optará [ por fazer ele ${ }_{i}$ o pequeno al.]]]

We conclude that the paradigm discussed consitutes a strong case not only in favor of a non-movement account of obligatory control but also in favor of the view that the pronoun is a subject of the infinitival complement.

3. Analysis. In her paper, Szabolcsi (2009) applies the above mentioned tests to a series of languages and detects the existence of three different patterns:

(i) Languages that do not admit expressed subjects either in control or in raising complements; this is the case in English, German and French.

(ii)Languages that allow for explicit subjects in raising and control complements; this is the case of Hungarian, Italian, Romanian, Turkish, Brazilian Portuguese (as well as EP).

(iii) Languages that allow for expressed subjects only in raising complements, like Russian, Finnish and (possibly) Hebrew.

Looking at Szabolcsi's sample, there appears to be correlation between consistent prodrop and pattern (ii): all of the consistent pro-drop languages in the sample fall under pattern (ii). It is this correlation that we wish to explore here. Our proposal has the following key features:

1. Barbosa (1995), Pollock (1997), Alexiadou and Anagnostopoulou (1998), among others, proposed that, in consistent NSLs of the rich agreement type, Agr is invariably "(pro)nominal" in the sense that it has a D/N feature capable of checking the EPP in T. The particular implementations of this proposal vary, but the basic idea is that the set of phifeatures in $\mathrm{T}$ is valued and interpretable, thus behaving like a pronominal clitic.

2. Belletti (2005) as well as Torrego (1996) propose to deal with the issue of the overt subjects of infinitivals in termos of the configuration of Clitic Doubling. This is also our take on the matter. In the VS case, the configuration in question is the following:

(13) $[$ тр [т [V [Agr] ] [V/vP subject ... ]]

L Agree

3. Extending this view to (noninflected) infinitival constructions, we suggest that the infinitival morpheme $-r$ is interpretable (in the consistent NSLs) and that the only difference between inflected and non inflected infinitival clauses is that non-inflected infinitival cl Agr is anaphoric (as originally proposed in Borer (1989)).

For the raising infinitival complements (cf. (5)), the analysis is straightforward: infinitival cl Agr checks the EPP in the embedded clause and finite cl Agr checks the EPP in the matrix; there is no expletive pro and the agreement affix in the matrix establishes a long distance Agree relation with the in situ subject of the embedded clause.

(14) [ т р [т acab-ou] [por [тр [т ir] [vP [ [ele] / [o João] [ ao mercado ...]]]

According to Szabolsci, the NSLs and Finnish/Russian behave alike (only) in the raising cases. This follows under the assumption that in all of these languages subjects may stay in situ and establish a long distance Agree relation with matrix T/Agr. In fact, Holmberg (2005) shows that subjects may stay in situ in Finnish and Bailyn (2004) makes a similar claim for 
Russian.

Our approach to control infinitives follows Landau's (2004) Agree-based theory. Following Borer (1989), Landau suggests that infinitival I/T contains a [-R] feature. In addition, Landau asumes that PRO is an anaphor (that is, it is $[-\mathrm{R}]$ ) and that only a $[-\mathrm{R}]$ element can check the $[-\mathrm{R}]$ feature of I/T. Associating these ideas with our suggestion that (noninflected) infinitival cl Agr in a NSL is nominal/interpretable and anaphoric, this means that infinitival cl Agr is [-R]. Thus, it is active to establish an Agree relation with Agr or $v$ in the matrix, thus co-indexing its own features with those of the antecedent. For this reason, the argumental subject is free to be either PRO or an overt pronoun. Agree between the affix and the subject argument (PRO or a lexical pronoun) guarantees coindexation between the antecedent in the matrix and PRO or the lexical pronoun (note that cl-Agr is interpretable, hence accessible to the higher Phase):

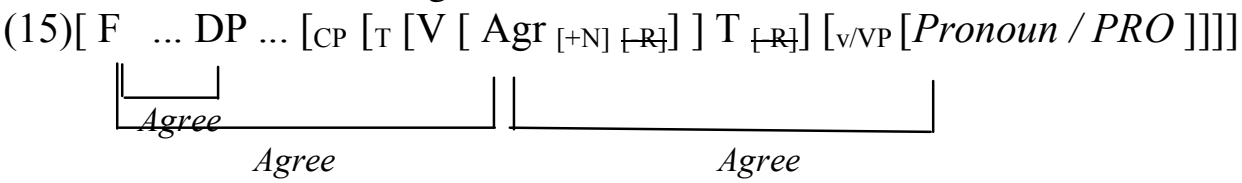

In the languages where Agr is not nominal, however, the uninterpretable [-R] feature in $\mathrm{T} / \mathrm{I}$ can only be checked by a [-R] subject argument and this is why only PRO is admitted. In other words, what enables the presence of the explicit pronoun in OC infinitives in the consistent NSLs is the fact that it doesn't directly check any uninterpretable feature in T.

\section{References}

Alexiadou, Artemis \& Elena Anagnostopoulou (1998) Parametrizing AGR: Word Order, V-Movement and EPPChecking, NLLT 16, pp. 491-539.

Alexiadou, Alexiadou, Anagnostopoulou, Elena, Iordachioaia, G. \& Marchis, M. (2008) 'A stronger argument for backward control', talk presented at NELS 39, Cornell University, November 2008.

Bailyn, J. F. (2004) Generalized Inversion. Natural Language and Linguistic Theory 22, 1-49.

Barbosa, Pilar (1995) Null Subjects, Ph.D. dissertation, MIT, MITWPL, Cambridge, Mass.

Barbosa, Pilar (2009) Two kinds of subject pro. Studia Linguistica 63. Blackwell Publishing.

Belletti, Adriana (2005) Extended doubling on the VP periphery. Probus 17-1: 1-35.

Borer, Hagit (1989) Anaphoric AGR, in Osvaldo Jaeggli and Kenneth J. Safir (eds.), The Null Subject Parameter, Kluwer Academic Publishers, pp. 69-109.

Burzio, Luigi (1986) Italian Syntax. Dordrecht: Reidel.

Cardinaletti, Anna (1998) A second thought on emarginazioni: destressing vs. 'right dislocation.' University of Venice Working Papers in Linguistics 8.2., 1-28.

Cardinaletti, Anna (1999) 'Italian emphatic pronouns are post-verbal subjects'. University of Venice Working Papers in Linguistics. Vol.9, 1-2.

Costa, João (1998) Word order variation. A constraint-based approach. The Hague: Holland Academic Graphics.

Holmberg, Anders (2005) Is there a little pro? Evidence from Finnish. Linguistic Inquiry 36: 533-564.

Hornstein, Norbert (1999) Movement and control. Linguistic Inquiry 30. 69-96.

Landau, Idan (2004). The scale of finiteness and the calculus of control. Natural Language and Linguistic Theory 22: 811-877.

Ordónez, Francisco (1998) Post-verbal asymmetries in Spanish. NLLT 16:313-346.

Polinsky, Maria \& Eric Potsdam (2002) Backward control. Linguistic Inquiry 33: 245-282.

Pollock, Jean Yves (1997) Langage et Cognition: Introduction au Programme Minimaliste de la Grammaire Générative. Paris: Presses Universitaires de France.

Raposo, Eduardo (1994) Affective operators and clausal structure in European Portuguese and European Spanish. Unpublished ms., University of California at Santa Barbara, California.

Szabolcsi, Anna (2009) Overt nominative subjects in infinitival complements cross-linguistically: Data, diagnostics, and preliminary analyses. NYU Working Papers in Linguistics, Vol. 2. Papers in Syntax, Spring 2009.

Torrego, Esther (1996) On quantifier float in control clauses. Linguistic Inquiry 27-1: 111-126. 